\section{2. 環}

\section{1 環境問題の動向}

\section{1. 地球環境問題の動向 ${ }^{1)}$}

地球温暖化, 成層圈オゾン層破壊, 酸性雨など地球 規模，広域環境問題に対する関心は依然として高い。 成層圏オゾン層破壊については, 特定フロン, 八ロン の規制スケジュールの前倒し，四塩化炭素， 1,1 , 1ートリクロロメタンの規制などが新たに決定された。 地球温暖化原因物質である二酸化炭素の化石燃料起 源排出量は，58.9億 $\mathrm{t}$ （炭素換算, 1988年）と推定さ れている。1990年 8 月の $\operatorname{IPCC}($ 気候変動に関する政府 間パネル) の第一次報告書では, 温暖化に対する科学 的知見, 環境・経済への影響, 対応戦略についての見 解が次のようにまとめられた ${ }^{2) 3}$ 。

1）温暖化将来予測特段の対策が講じられない と, 温室効果気体の濃度は 2025 年に $\mathrm{CO}_{2} 2$ 倍化に相当 するものになり, 全地球平均の気温上昇は約 $1{ }^{\circ} \mathrm{C}$, 2030年までの海面上昇は約 $20 \mathrm{~cm}, 21$ 世紀末までには気 温上昇が $3{ }^{\circ} \mathrm{C}$, 海面上昇は約 $30-100 \mathrm{~cm}$ 予測される。 温室効果気体濃度を現在のレベルに安定化するために は, 人為的な炭酸ガス排出量を $60 \%$ 以上削減する必要 がある。

2) 地球温暖化の影響 社会, 経済および自然の システムに多大な影響をもたらすことが予测される。

3 ) 地球温暖化対策 温暖化予測の不確実性の下 でも正当化される対策を直ちに開始すること。

地球温暖化対策については, 1990年11月の第 2 回世 界気候会議の閣僚レベル会合で検討され，次のような 閣僚宣言が出された。

1）不確実性を低減し，予測能力を高め，対応戦略 を立てるために, 調査研究活動を強化する必要がある ことおよび科学的確実性の欠如をもって，環境破壊を 防止するための措置を延期する理由とすべきでないこ と。

2）究極の目標は，気候への危険な人為的干渉を防 ぐレベルで温室効果気体濃度を安定化させることであ ク，第一段階として，世界経済の持続的な発展を確保 しつつ，モントリオール議定書で規制されていない温 室効果気体 (フロン, 八ロン, 四塩化炭素など以外)
の排出量を安定化する必要性を強調すること。

3 ）既存技術の再評価・改良，新技術の導入を含む 技術開発および技術の普及に対する各国の努力, 国際 協力を強化する。

4 ）条約を1992年国連環境開発会議までに締結す るべきことを確認する。

わが国では, 平成 2 年 10 月に「地球温暖化防止行動 計画」が決定された

基本的事項は,

1 ）環境保全型社会の形成

2）経済の安定的発展との両立

3 ) 国際的協調 (「地球再生計画」を含む) の 3 つである。

講ずべき対策として，次の 7 項目が挙げられている。 1 ) 炭酸ガス排出抑制対策

2 )メタンその他の温室効果気体排出抑制対策

3 ) 炭酸ガスの吸収源（森林等の緑）対策

4 ) 科学的調查研究, 観測・監視の推進

5 ) 技術開発とその普及

6 ) 普及・啓発

7 )国際協力の推進

「地球再生計画」は，今後約 100 年かけて地球を再生 することを目指し, 世界が協調して温室効果気体排出 抑制・削減のための総合的かつ長期的な行動を進める ことを提唱したもので (図 2-1), その推進の中核研 究機関として財団法人地球環境産業技術研究機構

(RITE: Research Institute of Innovative Technology for the Earth) が，11月に発足した。

\section{2. わが国の環境の現状 ${ }^{1)}$}

二酸化窒素, 二酸化硫黄, 一酸化炭素, 光化学才キ シダントと浮遊粒子状物質の 5 物質について環境基準 が設定されている。

二酸化硫黄の大気中濃度は昭和 42 年度の0.059ppm (年平均值) をピークに減少を続け，己こ数年，年平 均値は0.010ppm で推移している。平成元年度の環境 基準（1 時間值の 1 日平均值が $0.04 \mathrm{ppm}$ 以下であり, かつ， 1 時間值が $0.1 \mathrm{ppm}$ 以下であること）達成率は $99.5 \%$ あっあた。

一酸化炭素の大気中濃度も減少しており, 自動車排 出ガス測定局 (15) での年平均値は, ここ数年, $2.4 \mathrm{ppm}$ 


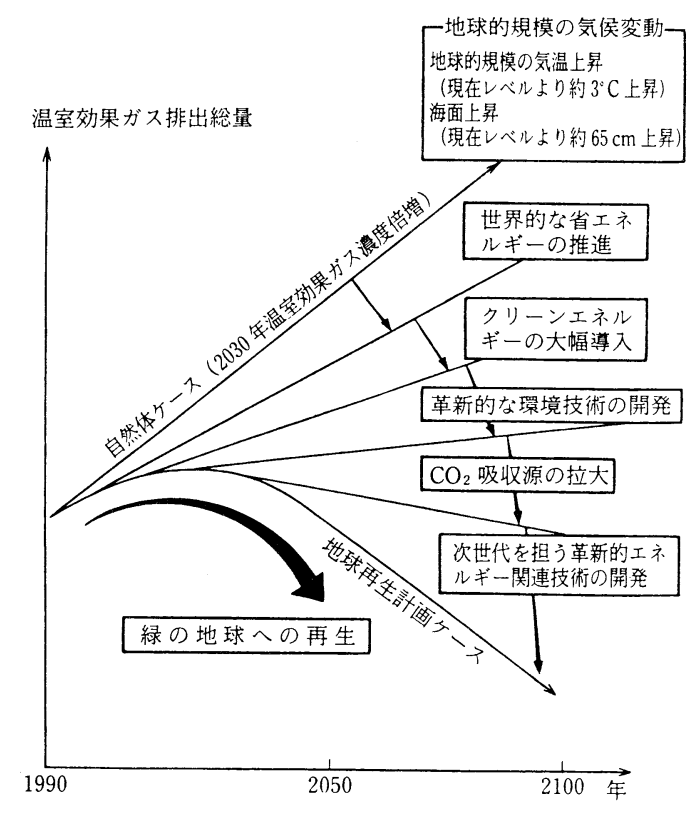

図2-1「地球再生計画」の概念（通産省資料より）

で変わっておらず，環境基準（1 時間值の 1 日平均値 が10ppm 以下であり，かつ，1 時間值の 8 時間平均值 が20ppm 以下であること）は，すべての測定局で達成 されている。

光化学オキシダント注意報の発令（光化学オキシダ ント濃度の 1 時間值が $0.12 \mathrm{ppm}$ 以上で, 気象条件から その状態が継続すると認められる場合）の日数は年に より変動してきた。平成 2 年度の発令日数は延べ 242 日 (関東 7 都県で117日) で, 元年度の63日より多くな っているが, 被害届出人数は増えていない。

二酸化窒素の大気中濃度は, 昭和 61 年度以降上昇傾 向に転じている。環境基準（1 時間值の 1 日平均值が $0.04 \mathrm{ppm}$ から0.06ppm までのゾーン内またはそれ以 下であること）の上限を超える測定局は，平成元年度 には，一般環境大気測定局65 (全測定局の $4.8 \%$ ), 自 動車排出ガス測定局106（34.5\%）になっている。特 に，窒素酸化物総量規制 3 地域では，環境基準非適合 局の割合は，一般局で $48 \%$, 自排局では約 $90 \%$ に達し ている。次節に窒素酸化物対策をまとめておく。

浮遊粒子物質（粒径 10 ミクロン以下の粒子物質）の 大気中濃度は, ここ数年横這いであり, 平成元年度の 年平均值は一般局で $0.039 \mathrm{mg} / \mathrm{m}^{3}$, 自排局で $0.049 \mathrm{mg} / \mathrm{m}^{3}$ であった。環境基準 ( 1 時間値の 1 日平均值が $0.10 \mathrm{mg}$ ) $\mathrm{m}^{3}$ 以下であり, かつ, 1 時間值が $0.20 \mathrm{mg} / \mathrm{m}^{3}$ 以下である
こと）の達成率は，一般局で $65.2 \%$, 自排局で $37.2 \%$ となっている。都市部での浮遊粒子状物質中には $20 \%$ 以上の黒煙が含まれており, 後述するディーゼルエン ジン排ガス対策の進展が望まれている。

以上，二酸化硫黄，一酸化炭素については環境基準 達成率が高いが, 二酸化窒素（窒素酸化物）と浮遊粒 子状物質については一層の対策, 特に移動発生源（自 動車) 対策が重要である。

\section{2 窒素酸化物污染 ${ }^{114) 5}$}

\section{1. 固定発生源対策}

固定発生源からの窒素酸化物対策は，昭和 48 年以 降，4次にわたり，排出基準の強化と対象施設の拡大 および 3 地域での総量規制が実施されてきた。低 $\mathrm{NO}_{\mathrm{x}}$ 燃焼技術として, 排がス再循環法, 二段燃焼法, 炉内 脱硝法, 低 $\mathrm{NO}_{\mathrm{x}}$ バーナーなどが開発され, ボイラーな どからの $\mathrm{NO}_{\mathrm{x}}$ 排出量低減が図られている。発電所など の大規模発生源については, アンモニアによる $\mathrm{NO}_{\mathrm{x}}$ の 選択還元（乾式選択接触還元法）を主力とする排煙脱 硝装置の設置が着実に増加している ${ }^{6) 7)}$ 。設置数は, 平 成元年度に 434 基に達しており, 処理能力は 159 百万 $\mathrm{Nm}^{3} / \mathrm{h}$ と排煙脱硫と同程度になっている1)。また，新 しい同時脱硫脱硝技術として, 活性炭を用いる方法 $\left(150^{\circ} \mathrm{C}\right.$ 程度の低温で稼働) や電子線照射とアンモ二 ア注入により，硫酸アンモニア，硝酸アンモニアとい う窒素肥料を回収するプロセスの実証試験が行われて いる6)8)

最近の窒素酸化物対策の特徵は, 燃料・燃焼技術の 多様化, 中小規模燃焼装置の増加にともなう新しい低 $\mathrm{NO}_{\mathrm{x}}$ 燃焼技術，脱硝技術の提案であろう ${ }^{9 / 13)}$ 。例之 ば，都市内部に建設されることの多いコージェネレー ションシステムには, 大規模な脱硝装置の設置, 液体 アンモニアの取扱いなどに制限がある。液体アンモ二 アに比べ法規制や取り扱いの容易なアンモニア水, 炭 酸水素アンモニウムなどを使用する脱硝装置の開発が 開始されている14)。

\section{2. 移動発生源対策}

大都市圈での窒素酸化物の排出源としては, 工場な どの固定発生源とともに, 自動車などの移動発生源の 寄与が大きい $\left(\right.$ 図 $2-2$ ) ${ }^{11}$ 。窒素酸化物対策として は，1）ディーゼル車を中心とする排出ガス規制の強 化，2）最新規制適合車への買い換之促進税制の検討, 


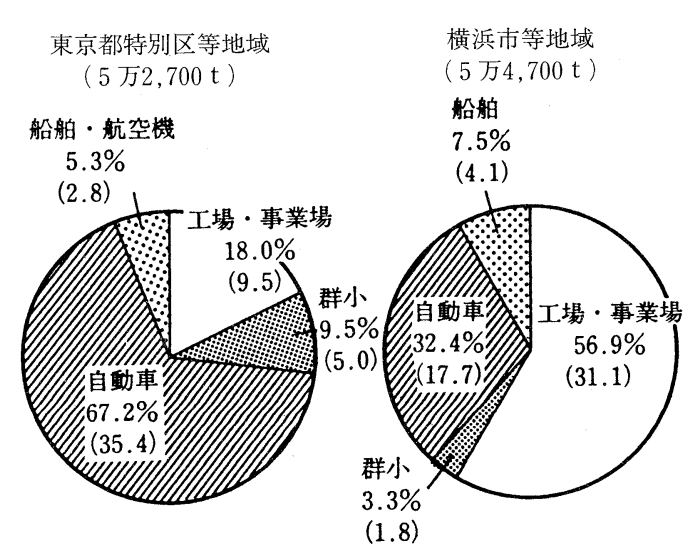

（備考）環境庁調へ。
大阪市等地域

$(4$ 万 $2,400 \mathrm{t}$ )

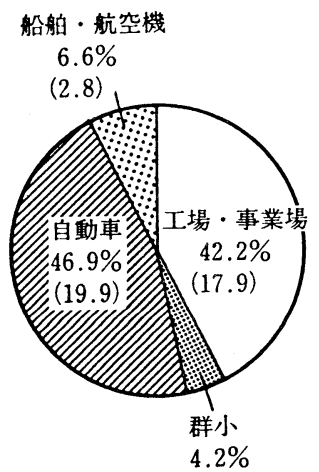

(1.8)

※( ) 内 千 $\mathrm{t}$

\section{図2-2 総量規制地域における発生源別窒素酸化物排出負荷の割合 (昭和60年度 $)^{1)}$}

3 ) 低公害車の普及促進，4 ) 自動車排出ガス総量抑制 に関する検討会の設置, 5 ) 公害健康被害補償予防協会 の基金による事業の推進, 6 ) 季節大気污染対策の推進 が，検討，実施されている4)。

自動車排出ガス規制による窒素酸化物低減効果（規 制前の窒素酸化物排出レベルを $100 \%$ とす）の推移 を見ると ${ }^{15)}$ ，ガソリン車では三元触媒の開発と適用に より，排出レベルは約 $8 \%$ まで減少したのに対し，デ イ一ゼル車では21〜47\%の範囲にあり, ディ一ゼル車 の窒素酸化物対策の強化がポイントになっている。

現在までのディ一ゼル車における窒素酸化物対策の 中心は，エンジン内での燃焼改善（燃料噴射時期の遅 延，燃料噴射系の改良，燃焼室形状の改善）と排出力゙ ス再循環（排出ガスの一部を吸気系に戻す方法）であ る。両方法には黒煙の増加, エンジン耐久性の低下な どの問題があり，軽油の深脱硫や潤滑油のグレード向 上が検討されている。また，軽油の代わりにメ夕ノ一 儿を燃料とし，窒素酸化物と黒煙の低減を図る技術開 発も開始されている16)。

ガソリン車に適用された三元触媒は，ディ一ゼル車 排ガスの性質 (高い酸素濃度, 低い排ガス温度, 多量 の黒煙等の粒子状物質）のために有効でない。このた め, 一酸化空素の分解反応 $\left(\mathrm{NO} \rightarrow \mathrm{N}_{2}+\mathrm{O}_{2}\right)$ を促進す る触媒として，銅イオンでイオン交換したゼオライト 系触媒, ペロブスカイト型複合酸化物触媒, 金属合金 系触媒などの検討が進められている ${ }^{17) ~ 21) 。 500 ~} \mathrm{C}$ 以上 の高温で NOの分解は進行するが, 実用化には, より 低温での分解活性の向上, 酸素, 水, 硫黄酸化物など
による活性低下の克服など, 多くの研究課題が残され ている。

最近，注目されているのは炭化水素を還元剤とする

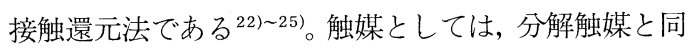
様なものが検討されているが, 酸素の存在する条件で, エチレン, プロピレンなどの炭化水素が共存すると, 200- $300^{\circ} \mathrm{C}$ 程度の温度で NOの還元が進行する。二酸 化硫黄が共存しても, $400^{\circ} \mathrm{C}$ 以上の反応温度で高い活 性が実現する。ディ一ゼル車へのアンモニアの搭載は 難しいが，炭化水素の排気への供給は容易と考之られ， 実用化に向けた研究開発が期待される。この接触還元 法はディーゼルエンジンコージェネレーションシステ ムなどの脱硝にも応用が可能であり, 設置面積の小さ な脱硝装置開発の観点から, 今後の開発動向を注目し たい。

\section{3 環境の酸性化（酸性雨）}

化石燃料の燃焼により大気中に放出される二酸化硫 黄, 窒素酸化物は26) 31)大気中で様々な過程で酸化さ れ，硫酸，硝酸となり，雨水などに含まれて地上に降 下する ${ }^{32)}$ 。その結果, ヨーロッパや北米北東部では湖沼 水, 土壤の酸性化による水産漁業資源の減少, 森林衰 退(図 2-3) 1)や建造物被害などが起こっている ${ }^{33)}$ わが国では昭和58年度より 5 か年にわたって, 環境 庁 (酸性雨対策検討会) により第 1 次酸性雨対策調査 


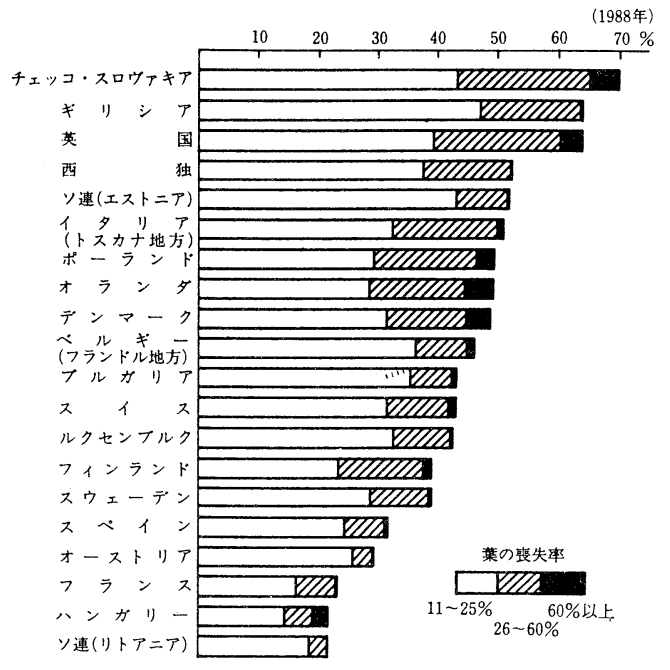

(備考) UNECE資料により作成。

\section{図2-3 ヨーロッパの森林の酸性雨や大気污染に よる被害1)}

が行われ，調查結果がまとめられた ${ }^{34)}$ 。長期モニタリン グとして昭和59年度から 62 年度まで全国14地点で，さ らに昭和61年度からは短期モニタリングとして15地 点が追加され, 降水の $\mathrm{pH}$ と硫酸, 硝酸などの主要イ オン成分の濃度と降水量が測定された。昨年の大気污 染学会等で, 調查結果が地域別に発表されている。以 下，その概要をまとめておく。

1) 雨水 $\mathrm{pH}$ の年間平均值 全国調查地点で 4.4 ～5.5の範囲であり，4 か年間に酸性化が進行した傾 向は見られず，地域的な差も余りない。

2) 硫酸イオンと硝酸イオン濃度硫酸イオン濃 度は日本海側で高く, 硝酸イオン濃度は首都圈などで 高い地域性がある。季節的には降雨量の少ないときに 都市部で濃度が高くなる傾向，札幌市，仙台市などで 冬季にカルシウム濃度の上昇（スパイクタイヤによる 粉じんの影響）が見られた。

3 ）イオン成分降下量硫酸イオン降下量は, 日 本海側や屋久島 (最高值 $7.42 \mathrm{~g} / \mathrm{m}^{2}$, 屋久島大忠岳 62 年 度) で多く, 硝酸イオン降下量は首都圈（最高値 3.50 $\mathrm{g} / \mathrm{m}^{2}$ ，武蔵野市，61年度) で多い傾向がある。硫酸 オン, 硝酸イオン降下量ともに, 日本海側や屋久島で 冬季に多くなる。

4) 欧米との比較学が国の硫酸イオン降下量は 欧米の降下量 (北米最大地域で $3 \sim 4.7 \mathrm{~g} / \mathrm{m}^{2}$ ) よりもか なり多い。硝酸イオン降下量も北米の最大地域の値 ( 2 $\left.\sim 3.4 \mathrm{~g} / \mathrm{m}^{2}\right)$ に近い。これらイオン成分降下量の割に は, 降水の年平均 $\mathrm{pH}$ の最低レベル4.41欧米の最低 值4.0に比べると高く, アンモニウムイオンやカルシ ウムイオンによる中和が考えられる。

5 ）生態系への影響 欧米では既に酸性雨による 湖沼水の酸性化が進んでいるが，わが国の133の湖沼 の調査結果では，ほとんどの湖沼が $\mathrm{pH} 7$ 付近に分布 している。土袞も同様で，12調查地点での土壤の $\mathrm{pH}$ は4.3〜6.8の範囲であり, $\mathrm{pH} 5$ ～6のものが全体の 約 7 割であり, $\mathrm{pH}$ の経年変化（5年間）も明瞭でな い。植物を含めて，わが国では酸性雨の生態系への影 響は，現時点では顕在化していない。

このような酸性雨が今後とも降り続くとすれば, 生 態禾への影響が現れることも䯚念される。環境宁では, 昭和63年度から大気, 陸水, 土壤のモニタリング, 酸 性雨発生予測手法の開発, 陸水, 土壤への影響予測調 查等を内容とする第二次酸性雨対策調查を実施してい る1)。また, 平成 2 年度からは, 酸性雨等の森林への影 響調査, 地球環境研究総合推進費による東アジアにお ける酸性, 酸化性物質の動態解明の研究が進められて いる1)。日本海側での高い硫酸イオン降下量と関連し て, 東アジア地域での酸性雨観測や国際研究協力の強 化は，今後の重要な研究課題である。また，大陸にお ける発生源対策（特に硫黄酸化物対策）に積極的に協 力することが必要かもしれない。

\section{4 地球温暖化}

\section{1. わが国の二酸化炭素排出（図 2-4）1）}

わが国の二酸化炭素排出量は，平成元年度で約 3 億 tである。排出源別にみると, 産業部門が約 9,200 万 $\mathrm{t}$ (全体の約 $32 \%$ ）であり，そのうち 3 分の 2 が鉄鋼, 穼業土石，化学，紙パルプの 4 業種で占められている。 民生部門では約 3 , 400万 t (12\%)，運輸部門では約 5 , 400万 t（19\%）を排出している。エネルギ一転換部門 (発電, 石油精製など) からの排出量は, 約 9,800 万 $\mathrm{t}$ （34.5\%）と最も大きな割合を占めているが，他部門 の需要を満たすための排出が大部分である。

\section{2. 二酸化炭素排出抑制}

個々の排出抑制技術については昨年の報告の中でも 述べたが35), 図 2-1の地球再生計画の中で, これらの 対策技術の展開，タイムスケジュールが整理されてい る。ここでは, 図 2-4の各部門, 業種について, 二酸 
化炭素排出抑制の方策として短期的な技術課題である 省エネルギー/エネルギ一利用効率向上を中心に検討 されているのを紹介しておく ${ }^{36)}$

電力業界では，原子力, 天然がスなどの積極的な導 大, 熱効率の改善, 送配電ロスの低減などにより, 過 去10年間で電力需要増加が1.34倍になったのに対し, 二酸化炭素排出量を 1.05 倍にとどめてきた ${ }^{37)}$ 。今後の 対策として，原子力の一層の拡大，高効率発電技術(石 炭がス化複合発電, 燃料電池など $)^{38)}$, 太陽光発電技術 などの開発，さらに，二酸化炭素の分離・回収，貯留・ 処分技術の開発と評価を進めている。

鉄鋼業界では，1973年に比べ，1988年の省エネルギ 一率は $20 \%$ 以上になっている39)。今後の省エネルギー 対策として，省工ネルギ一対策未実施設備への適用， 効率的設備への更新，排熱回収の推進や次世代製鉄技 術である溶融還元製鉄法の実用化が挙げられている。 また, 経済性のある高炉ガス中の二酸化炭素分離回収 技術の検討も進められている ${ }^{39)}$ 。

環境白書 (総説) では，「環境にやさしい交通運輸」 の節が設けられ ${ }^{1}$, 自動車からの二酸化炭素排出量 (軍 輸部門排出量の85\%）低減の重要性が指摘され，輸送 効率の向上，円滑な走行の確保などの対策が求められ ている。自動車業界でも従来から，排がス対策ととも に燃費の向上が図られてきたが，軽量化，走行抵抗の 低減，エンジン本体の効率向上などの技術開発が進め られている ${ }^{40)}$ 。更に, 低公害であり, 二酸化炎素排出量 も少なくなると期待される電気自動車, メ夕ノール自 動車, 天然ガス自動車, ハイブリッド自動車, ソーラ 一カーなどの開発も行われている1)

これら産業界での二酸化炭素排出抑制対策の中にも 見られるが, クリーンエネルギーの大幅導入のための 研究開発が通商産業省のサンシャイン計画, RITEな どの事業として行われている。

平成 2 年度 7 月に, サンシャイン計画の今後のあり 方が産業技術審議会新エネルギー技術開発部会から報 告されている。太陽エネルギー，地熱工ネルギ一，石 炭液化・ガス化, 水素エネルギー, 風力エネルギー, 海洋工ネルギー，バイオエネルギーなどの利用に向け て，地球環境問題への最大限の対応を考慮した技術開

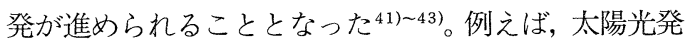
電は，近い将来に実用化が期待される新工ネルギー技 術の一つであり，太陽電池製造コストの低減が図られ てきた(平成元年度で $1 \mathrm{~W}$ 当たり720円)。また, 平成 4 年度までに電池の工ネルギー変換効率を単結晶で 15\%から $18 \%$ ， アモルファスで10\%から $12 \%$ 向上

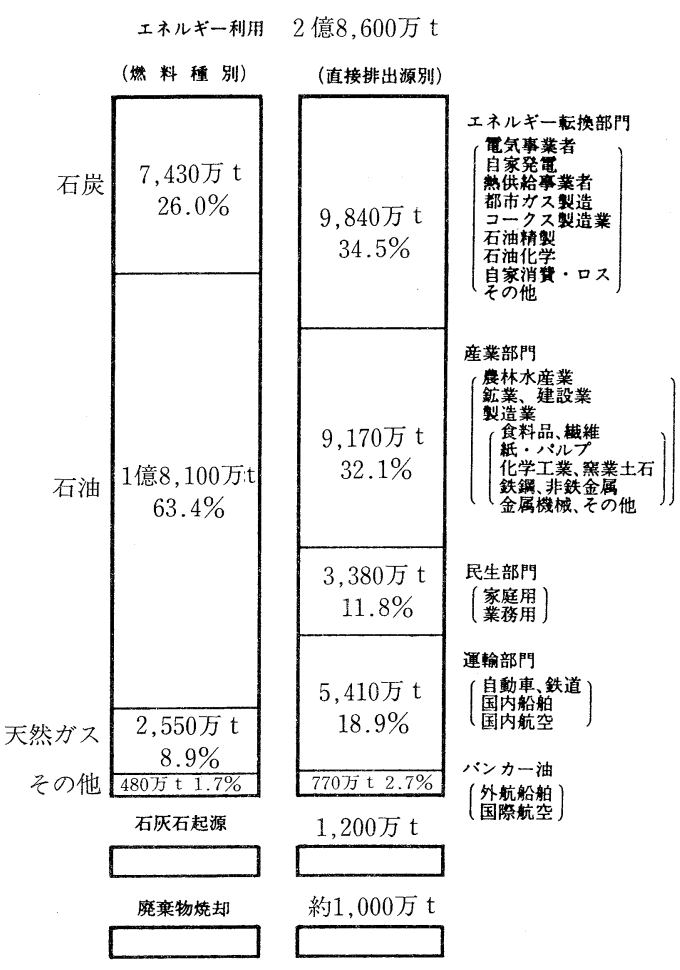

（備考）1、総合エネルギー統計等より試算。

2. 值は炭素換算。

3、\%はエネルギー利用全体に対する割合。

4. 廃棄物焼却は1988年度の資料を用いた。

\section{図2-4 わが国の二酸化炭素排出量}

(炭素換算 $)^{1)}$ (1989年度)

させる研究が行われている。更に, 平成 2 年度からは, 超高効率太陽電池開発の研究が開始されている。

RITE での研究開発は, 平成 2 年度より開始された が，第 3 世代フロンの開発研究，生分解性プラスチッ クの開発研究などに加えて，次に示すような二酸化炭 素の固定化・有効利用技術の開発が中心になってい る $^{44)}$ 。

1 ) 細菌・藻類等利用二酸化炭素固定化 - 有効利用 技術

微生物等のもつ光合成機能を人工的に高密度に集積 化し，太陽エネルギーによる二酸化炭素変換システム と光合成生成物の利用を目的とするもので，(1)高効率 光合成微生物等の研究, (2)太陽光高効率集光利用技術, (3)二酸化炭素固定化バイオリアクターの開発, (4)光合 成生成物からの有用物質生産技術の開発, トータルシ ステムの開発，などからなっている。 


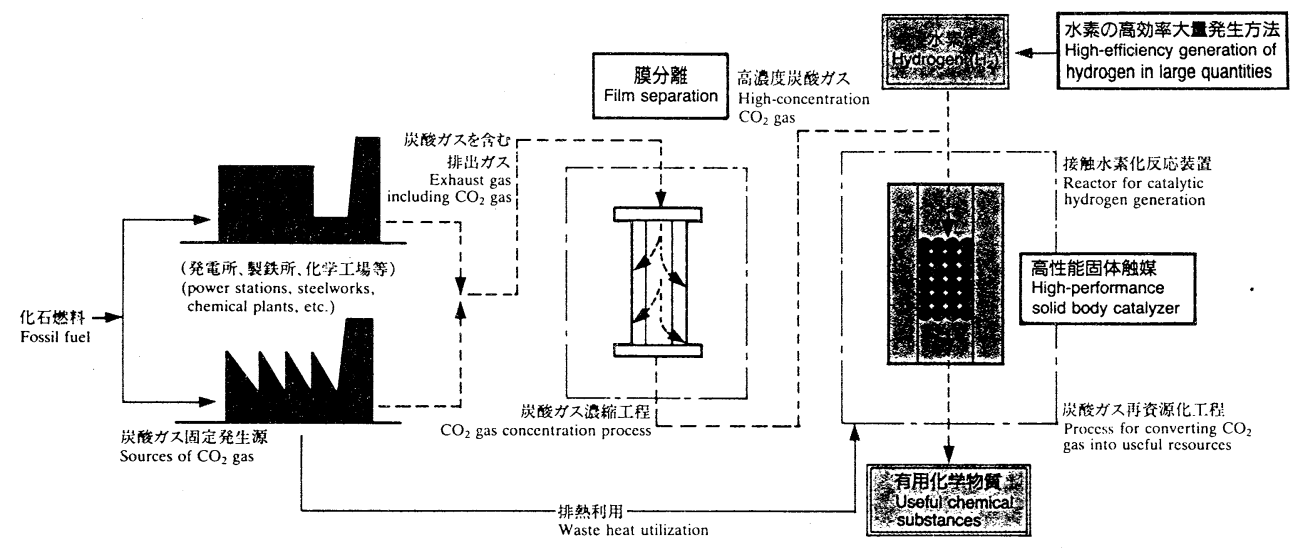

図2-5 二酸化炭素の接触水素化処理技術の体系（RITE 資料より）

2 ）接触水素化反応による二酸化炭素固定化・有効 利用技術（図 2-5)

固定発生源からの二酸化炭素を大量かつ連続的に回 収し，水素との接触反応によるメ夕ノール等の有用物 質への変換を目的とするもので，(1)高効率二酸化炭素 分離膜の開発，(2)水素化反応用高効率低温触媒の開発, (3トータルシステムの開発，などからなっている。い ずれもすぐに実用化できるものではないが，二酸化炭 素の排出抑制ばかりでなく，二酸化炭素の有効利用あ るいは資源化も観点にいれた研究課題であり, 研究開 発にともなう技術的な波及効果も期待されている。

\section{文献}

1 ）環境庁，環境白書平成 3 年版（1991） International Panel on Climate Change, IPCC First Assessment Report Overview

3 ) 編集 室，公害と対策，26，6 4 ）宮崎正信，燃協 誌，69，76 5) 伊藤 浩，産業公害，26，925 6 ）野口嘉一, 燃協誌，69，84 7) 中島史登, 触媒，32，236 8) 青木慎治, 燃協誌，69，165 9 ）永井建夫，燃協誌，69，100 10）飯田弘文, 燃協誌，69, 107

11）原田英一，燃協誌，69，112 12）石川芳 治, 燃協誌，69，118 13）系川英樹，燃協誌， 69, 122 14）小林謙一朗, 他, 公害と対策, 26, 23 15）大井明彦，燃協誌，69，92 16）瀬古俊之, 燃協誌，69,172 17）岩本正和, 燃協誌，69,156
18) Teraoka Y., et al., Chem. Lett., 1 Yasuda, H., et al., J. Chem. Soc. Chem. Commun., 1094 20）岩本正和，触媒，32，91

21）小㴊存, 他, 窒素酸化物の除去, 「大気の化 学」, 季刊化学総説, 10, $181 \quad$ 22) Held, W., et al., SAE Paper, 13 23) 岩本正和, 他, 触媒, 32, 430 24) Hamada, H., et al., Appl. Catal., 64, L1 25) Kintaichi, Y., et al., Catal. Lett., 6, 239 26）安田憲二, 公害と対策, 26, 1379 27）福岡三郎, 同上, 26. 1383 28）柳沢三郎, 他，同上，26，1389 29）草野 一, 同上，26, 1395 30）谷川 昇, 同上, 26, 1399

31）藤田慎一，同上，26，1412 32）指宿克 嗣, 酸性雨 (環境の酸性化) の原因物質, 「大気の化 学」, 季刊化学総説, 10,99 33) 石 弘之, 公害 と対策, 26, 137134 ) 環境预, 酸性雨対策調查 報告書 35）公害資源研究所地球環境特別研究 室編，地球温暖化の対策技術，オ一公社 36）卜 リガー, 地球環境/科学技術は地球を救えるか 37）瀬間 徹, 機誌, 94, 310 (1991) 38) 化学 工学会ワーキンググループ, 化学工学, 54, 44 39）日本鉄鋼連盟, 鉄鋼界, 7 月号 40）竹辺 孝, 機誌, 94，306 (1991） 41）河面慶四郎, 燃 協誌，70，10（1991） 42）藤嶋 昭, 他, 燃協誌, 69, 343 ) 谷 辰雄, 燃協誌, 69, 15 44)徳 增有治, 化学工学, 54, 2 (RITE 資料) 